\title{
Praise and Censure to Female, Beauty or Evil-Recognition of Noble Concubine Yang, Classical Beauty of China
}

\author{
Lirong Jiang \\ Yibin Uiniversity, Yibin 644000, Sichuan, China \\ Email: profj_phoe@163.com
}

\begin{abstract}
For years Chinese literature output has very big deficit, especially for Euramerican deficit is about 100:1 above. In recent years many translators devoted to the introduction of Chinese literature to the world. The National Social Science Fund conducted long-term foreign translation project of Chinese academic programs. This article tries to restore a real female image of Chinese classical beauty in the literary works through recognition of noble concubine Yang, and is devoted to let the world re-know this literary image. Noble concubine Yang Yuhuan was the first of the four classical beauties in ancient China. Another three were Xi Shi, Wang Zhaojun, and Diao Chang, with the idiom "the beautiful women shame the moon and flowers" describing the four. Noble concubine Yang Yuhuan was also the beautiful woman with highest status and biggest authority among the four in ancient China, as well as an imperial concubine who was largest affect in the world in China's feudal dynasties. In the Chinese history, did not any woman have to be richer than noble concubine Yang's story the romantic and full of legend color. "Beauty is the cause of evil" has been the excuse of men to cover their mistakes in history. In number of writings noble concubine Yang was described as this. However in some other words Yang's beauty was pure and her nature was kind in such struggle of the imperial palace. Her love was sincere. According to some historical material and even some tales we can have recognition of this unique beauty in China's ancient history.
\end{abstract}

Index Terms—Noble Concubine Yang, female, beauty, evil

Noble concubine Yang (Yuhuan)was the first of the four classical beauties in ancient China. Another three were Xi Shi, Wang Zhaojun, and Diao Chang, with the idiom "the beautiful women shame the moon and flowers" describing the four. Yang Yuhuan was also the beautiful woman with highest status and biggest authority among the four in ancient China, as well as an imperial concubine who was largest affect in the world in China's feudal dynasties. In the Chinese history, did not any woman have to be richer than noble concubine Yang's story the romantic and full of legend color!

Yang Yuhuan originally was wife of prince Li Mao, Emperor Tang Xuanzong's son. Xuanzong Li Longji was attracted by her beauty and couldn't control himself from getting her, helped by the Unofficial Gao Lishi, Xuanzhong first made her the female Taoist, giving her the title Taizhen. In the fourth year of Tianbao she was conferred rank and title officially for noble concubine. "Beauty is the cause of evil" is the excuse of men to cover their mistakes in history. In number of writings noble concubine Yang was described as this. However in some other words Yang's beauty was pure and her nature was kind in such struggle of the imperial palace. Her love was sincere no matter to $\mathrm{Li} \mathrm{Mao}$ and $\mathrm{Li}$ Longji. She should not be responsible for the Rebellion of An and Shi ${ }^{1}$ of Tang dynasty.

\section{NATURAl BeAuty AND Being TALENTED With MusiC}

Yang Yuhuan (719-756 A.D) was born in Rong County, Canton, later came into Sichuan because her father was sent to be an official there. When she was ten years old her father died. Her uncle took her to Luoyang and educated her until one day she met with Li Mao, one of sons of the Tang emperor. At that time Luoyang was the east capital of Tang, every year the emperor Xuanzong(Li Longji ) would be there for a long time with his family members. So at the age of 17 Yang Yuhuan became a princess of Prince Shou, Li Mao. Later the emperor saw her closely at the palace of his favorite concubine Wu, Prince Shou's mother. Then the emperor would never forget Yang's beauty. After concubine Wu's death the emperor even felt other concubines monotonous. He was often in a state of utter stupefaction and he even had no desire for the affairs of imperial court. His unofficial Gao Lishi knew what he wanted. Helped with princess Yuzhen, Li Longji's younger sister, Gao arranged Li and Yang dated several times. The emperor was not satisfied with only such dates. He wanted to have this beauty permanently. Then Yang Yuhuan was made female Taoist, given the title Taizhen when she was 22 years old. In the palace there was a Taoist temple named Taizhen Temple where she lived and dated with the emperor for 5 years. In the fourth year of Tianbao she was conferred rank and title officially for noble concubine.

\footnotetext{
${ }^{1}$ Rebellion of An and Shi: That was an important event in the tang dynasty even in the history of China, a turning point of Tang dynasty from being glorious to declining. An refers to AN Lushan(also AN Qingxu), Shi to SHI Siming (also SHI Chaoyi).They started a revolt against Tang dynasty since Tianbao 14 year of Tang Xuanzong ( 755 A.D. ) to the beginning year Baoying of Tang Daizong (762 A.D.). It lasted for eight years.
} 
"Turning her head, she smiled so sweet of grace. That she outshone in six palaces the fairest face" (Xu, 2003). This was described by Bai Juyi in The Everlasting Regret. Noble concubine Yang was so beautiful that all the women in the palace were dark comparing with her. Yang Yuhuan was familiar with music, talented with dancing. The famous "Rainbow Skirt and Feathered Coat." was her choreography. For the large dance, the emperor himself composed, the emperor ordered to set a special theatre. Such a large dance has come down in Chinese history and today it is also played in Xi'an, once the ancient capital. "In revels as in feasts she shared her lord's delight, /His companion on trips and his mistress at night./In inner palace dwelt three thousand ladies fair;/On her alone was lavished royal love and care." Now the emperor's love was given to Yang alone. "Seeing slow dance and hearing fluted or stringed song,/The emperor was never tired the whole day long" (Xu, 2003).

Sometimes she was little capricious. Twice she was sent out of the palace but soon she was taken back every time because the emperor couldn't live without her. Her sisters and cousins were given treasures and official. She saw the serious problem of this. And she would like to stop it but in vain. That was foreshadowing for her tragic fate.

\section{LOYAL TO LOVE WITHOUT INTERVENING ROYAL AFFAIRS BUT A ViOLENT DEATH}

“All her sisters and brothers received rank and fief, /And honors showered on her household, to the grief" (Xu, 2003). Because of her rank, the emperor gave her family official positions and wealth. Her foster father was advocated Confucianism and angry with her change from a princess to a noble concubine of the emperor. Not long after he was dead because of being terrified restless. Yang Yuhuan's three female cousins separately got the title of Noble Madame Qin, Han and Guo. Another cousin named Yang Zhao got appreciation from the emperor for his talent and was promoted repeatedly until he became the prime minister. The Emperor changed Yang Zhao's name to Yang Guozhong. Yang Guozhong himself took part in some struggle of the palace and other family members sometimes were arrogant in capital city. Noble concubine Yang realized her family got too much from the emperor. She had a little worry and once asked the emperor to take something back from her cousins. But the emperor did not pay attention to her suggestion. The emperor even loved her more because she did not intervene in affairs of the royal government. Even someone asked her to help her former husband Li Mao to become crown prince, she thought it over and decided not to trouble the emperor. She knew that Li Mao had no such ability to be the crown prince. Gradually she transferred her whole love to the Emperor only. On the night of July 7, Chinese lunar calendar, she asked the Emperor with her to pray to Altair and Vega, "hoping to be the husband and wife forever" (Nan, 2005)! To Yang Yuhuan, she was satisfied with love and music. She arranged the large-scale palace dance: "Song of Rainbow Skirt and Feathered Coat", which was composed personally by the emperor himself. She had a group of actors and actress and led them to practice, sinking happiness.

"But rebels beat their war drums, making the earth quake / And 'Song of Rainbow Skirt and Feathered Coat 'broke" (Xu, 2003). The Turmoil of An and Shi in Tang Dynasty broke out in 755 and forced the emperor to flee from the capital to Sichuan. On the $2^{\text {nd }}$ afternoon after they left Chang'an, they arrived Mawei Slope, southwest Xingping County, Yang Yuhuan's cousin, prime minister Yang Guozhong was accused to have plots of rebellion. He was killed by the angry palace guard soldiers. Those traitorous soldiers asked that noble concubine Yang must also be killed or they wouldn't escort the emperor. The emperor was very angry with great pain and grief. He shouted: "What does this matter with the noble concubine since she has been in deep palace, how does she know the prime minister's rebellion?" "The "noble concubine is innocent" (Nan, 2005)! But in such critical time piteous Yang Yuhuan had no other choice except death for her country. Then the first beauty of China was hanged in the hall for worshipping the Buddha of Mawei Slope. "The monarch could not save her and hid his face in fear;/ Turning his head, he saw her blood mix with his tear" (Xu, 2003). After noble concubine Yang died, her corpse was ordered to be put down on a plank in the station garden, the imperial guard military officers Chen Xuanli etc. were invited to come in autopsy. After having looked, Chen Xuanli with other officers only then had taken off their armors and helmets, kowtows to the emperor to apologize.

\section{TALES AFTER NOBle CONCUBINE YANG'S DEATH}

Noble concubine Yang died, and the emperor harbored regret all day long since that. In order to give expression to his grief over Yang's death he even carved a small statue of Yang himself. But there has been another legend about noble concubine Yang. She didn't die on Mawei Slope. Common people would like to believe as well as spread this. After she was put down on a plank autopsy, the emperor and soldiers went on. Her close maidservants who left to handle the things after her death felt that she still had weak breath. One of them made rescue breathing for her. After a while Yang resurrected herself in a miracle. In order to cover the fact they made a dummy and buried it. With the help of Li Mao, Yang's former husband, several close eunuchs and maidservants escorted Yang to escape from another way, not to Sichuan, but to a road from Hanshui River down eastward. On the way they met an old music worker who then followed Yang faithfully. After arriving Xiangyang they bought a twin mast's river boat and employed the local boatmen, taking the canal to Jiangxia, then eastward along the Yangtze River until they arrived Yangzhou. In Yangzhou they heard a version: noble concubine Yang did not die in Mawei event(Nan, 2005)! They stayed in Yangzhou nearly half a year then occasionally they met Yang Guozhong's daughter-in-law Xu with her son, who lived in the same city with Japan's envoys. Xu told them during the Mawei event her son and her were not together with her mother-in-law and they escaped their lives with the help of one of their old servants. Then they met with the Japan's envoys, who accepted them 
because Xu's husband had been in charge of foreign affairs and the old servant knew those envoys. Because the current political situation was serious, Xu had decided to take her son to go to Japan with Japan's envoys. Tengyuan, the head of Japan's envoys, urged to ask noble concubine Yang to travel eastward to Japan. After a deep thought and a long discussion, noble concubine Yang brought $\mathrm{Xu}$ and $\mathrm{Xu}$ 's son to Japan with the envoys, along with them so many four seasons clothes, all kinds of gift and the apparatus produced in Yangzhou, several big boxes of the gift department, several big boxes of the apparatus department, one box is the stationery aspect, only various types of writing brushes 750 , in addition, also two boxes of various types books, from the writing of ancient Laotze, Confucius to modern Li Bai's prose. Those had been purchased in Yangzhou city, giving first to the Japan envoys.

According to Japanese ancient times fable: noble concubine Yang and the party of people arrived in Japan A.D. 757 years, it was said that the ship she took landed in Ogimachi of Laihu inland sea mountain pass. Another saying was that noble concubine Yang landed in Zyuzin County. In Yamaguchi Prefecture of Japan, the "township of the noble concubine Yang", there is noble concubine Yang's grave. In 1963 a Japanese girl demonstrated a genealogy to the television viewer, saying that she was noble concubine Yang's posterity, the Japanese famous movie star Yamaguchi Momoe also said she was noble concubine Yang's descendant.

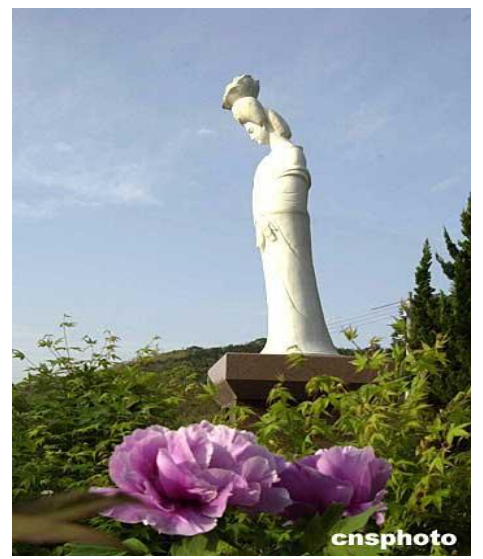

(noble concubine Yang's statue in Japan, in front of her grave in Zyuzin County) (Gao, 2007)

During Expo 2010, Shanghai, there was a copy boat of Japan's envoys exhibited at Japan Pavilion. It was said that copy boat started from Osaka, along the ancient envoys' tracks, one month later arrived in Shanghai. Meanwhile Dinner of Noble Concubine Yang was exhibited at Japan Pavilion.

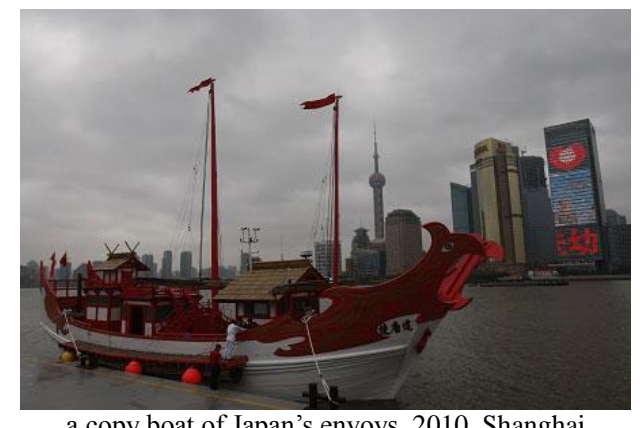

a copy boat of Japan’s envoys, 2010, Shanghai

Folklore noble concubine Yang's death and resurrection reflected people with fondly memory and sympathy to her. After the wind and rain of Anlushan's Rebellion people started to reconsider the historic Tianbao chaos, and realized finally to the historical truth, the folklore innate fair judgment. It is quite often objective to historical personage's appraisal, death of the noble concubine Yang already had one side which it had only herself to blame, the other side she had achieved the name of a sacrificial victim, therefore people fantasized noble concubine Yang could reactivate. Perhaps it was just infinite memory from people. "Where 'mid the clods beneath the slope he couldn't forget, /The fair-faced Lady Yang, who was unfairly slain” (Xu, 2003). On the way back to the capital the emperor asked Gao Lishi reburied noble concubine Yang, but they did not find Yang's corpse. After the emperor came back to Chang'an, he asked "Linqiong Taoist" to seek for Yang everywhere. "He learned that on the sea were fairy mountains proud / that now appeared, now disappeared amid the cloud" (Xu, 2003). It was said Li Longji sent a special envoy with a small statue of noble concubine Yang to Japan seeking for Lady Yang. Japan also sent an envoy to bring back Lady Yang's news. But they were thwarted to see Li Longji by the present emperor Daizong, Li Longji's son. It is also said that the overlord Li Longji's final years were very chilly pain, day and night he was missing in overseas Lady Yang(Nan, 2005). "Fireflies flitting the hall, mutely he pined away; /The lonely lampwick burned out; still he could not sleep." "One long, long year the dead and the living were parted; / Her soul came not in the dream to see the brokenhearted" (Xu, 2003). It was said 
the statue of Lady Yang in Japan is the same as the one at Mawei Slope of China.

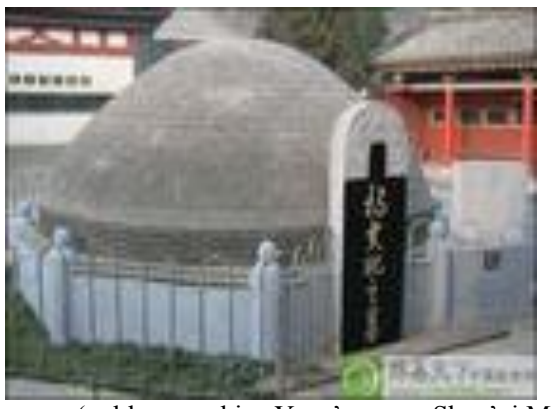

(noble concubine Yang's grave, Shan’xi Mawei Slope)

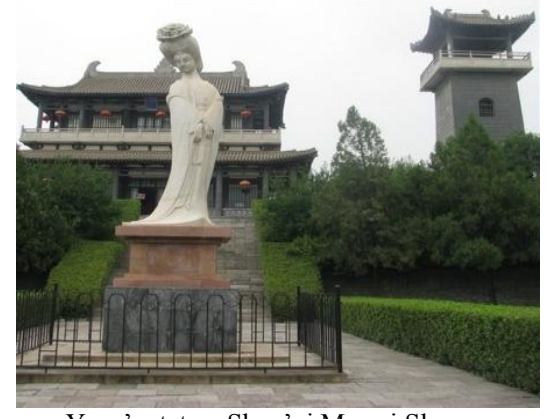

Yang's statue, Shan'xi Mawei Slope

\section{CONCLUSION}

Looking all about several thousand long history annals of China, noble concubine Yang was not Zhao Feiyan, a beautiful woman in Han dynasty of China who waited on the emperor with the world outstanding person favors in the harem. When Tang Xuanzong asked great poet Li Bai to create "Qingpingle Three Chapters" to praise Lady Yang's beauty, there was "Asking Han Palace who was the same as her, the poor Feiyan must rely on new dress" (Wang , 2009) . Noble concubine Yang was not Wu Zetian, the only orthodox empress in China's history who seized the throne by her beautiful appearance and plotted power. Noble concubine Yang was not Empress Dowager Cixi, who attended to state affairs by the unrivalled ambition in the court discipline. Noble concubine Yang was herself, above her peerless beautiful appearance was the valuable purity. She fell into the power and influence was her natural disposition goodness, and her love was a pay of true feelings! The years flowed on, the emperor had three thousand beauties in his palace, it was natural he moved his love from one to one. But facing with such exciting fighting of the palace, for 11 years Yang Yuhuan, without aid and without her own party, without using any trick, became the noble concubine to manage the whole harem, at last the emperor Xuanzong loved her only. Their love became a poetic masterpiece through the ages in the Chinese history. Noble concubine Yang Yuhuan was a beauty but not the cause of evil. She was only a most beautiful woman in China's history, who lives in people's mind and appear on the contemporary screen by the lifelike most beautiful woman!

For years Chinese literature output has very big deficit, especially for Euramerican deficit is about 100:1 above. In recent years many translators devoted to the introduction of Chinese literature to the world. The National Social Science Fund conducted long-term foreign translation project of Chinese academic programs. I hope more and more Chinese literary works to be introduced to the world and let Chinese literary art treasures glint in the world.

\section{REFERENCES}

[1] JIN Sidun. (2003). The Soul is Drunk by the Very Beauty: Yang Yuhuan. Beijing: Popular Literature Publishing House

[2] NAN Gongbo.(2005). Beauty in Tumultuous Times: Noble Concubine Yang. Shanghai: Wenhui Publishing House

[3] XU Yuanchong (2003). Bai Juyi. The Everlasting Regret. A Practical Coursebook on Translation. Shanghai: Shanghai foreign Language Education Press

[4] ZHENG Wen. (2001). Rebut a False Charge for Noble Concubine Yang. Gansu Society Science, 1, 65-68

[5] GAO Shihua. (2007). The Everlasting Regret and Noble Concubine Yang in Japan----Visiting the Tomb of Concubine Yang in Japan. Studies the Digests, 9, 124-127

[6] JIANG Lirong. (2005). Form, Spirit and Rhyme--- reading three English versions of 《Chang Hen Ge》. Linguitic Research \& Application, 3, 69--74

[7] WANG Yimei. (2009). Why is the Love Tragedy of Emperor Tang and his Noble Concubine Yang Widely Known and Never Fade. Literature Education , 3, 142-143

[8] YE Guangning.(2003). Noble Concubine Yang in Japan ---From Mawei Slope to the Xiangjinju Peninsula Prose. Mountain Flower, 3, 79---83

[9] Orient Morning Post June 10, 2010

Lirong Jiang was born in Luzhou, China in 1956. She received her BA degree of foreign language \& literature from Southwest Normal University in 1982 and Certificate of advanced visiting scholar from Beijing Foreign Study University in 2004.

She is currently a professor in Yibin University, Yibin, China. Her research interests include translation \& intercultural communication.

Professor JIANG is a councilor of Translators Association of China 